\title{
Assessing Sustainability of Rainfed Wheat (Triticum Aestivum) Production under Various Soil Tillage Systems: An Energy and Economic Analysis
}

\author{
Rana Shahzad Noor ${ }^{1,2}$, Fiaz Hussain ${ }^{2}$, Irfan Abbas ${ }^{3}$, Muhammad Umair ${ }^{2}$, Abu Saad ${ }^{2}$, Muhammad Umar \\ Farooq ${ }^{4}$ and Yong Sun ${ }^{1 *}$
}

${ }^{1}$ Department of Agriculture, Biological, Environment and Energy Engineering, College of Engineering, Northeast Agricultural University, Harbin 150030, China; ${ }^{2}$ Faculty of Agricultural Engineering and Technology, PMAS-Arid Agriculture University, Rawalpindi 46000, Pakistan; ${ }^{3}$ School of Agricultural Equipment Engineering, Jiangsu University, Zhenjiang 212013, China; ${ }^{4}$ College of Hydraulic Engineering, Yunnan Agricultural University, Kunming Yunnan, 650204 P.R China.

Abstract | Energy management is an essential component in sustainable agricultural production systems. The study was mainly designed to evaluate the impact of four kind of soil tillage as; No/zero tillage (ZT), conservational tillage (PT), reduced tillage (RT) and conventional tillage (CT) on wheat yield, fuel usage and energy use efficiency under rainfed agriculture systems for Chakwal-50 wheat cultivator at Koont research station of PMAS-Arid Agriculture University, Rawalpindi during 2018 and 2019 wheat seasons. The study treatments were evaluated in term of energy analysis and economics of wheat production. Highest energy inputs obtained were fertilizer, seed and fuel + oil energies in all tillage systems for wheat sowing, respectively. Results interpretation indicated that the highest $\left(2,300 \mathrm{kgha}^{-1}\right.$ and $\left.40.56 \mathrm{lha}^{-1}\right)$ and lowest $\left(1,930 \mathrm{kgha}^{-1}\right.$ and $8.97 \mathrm{lha}^{-1}$ ) wheat yields were measured in $\mathrm{CT}$ and ZT farming treatments, respectively. The maximum and lowest energy values were calculated in PT (6.03) and CT (5.14), respectively. The maximum specific energy measured was $\left(7.17 \mathrm{MJ} \mathrm{kg}^{-1}\right)$ in ZT treatment, while the least specific energy was calculated in the RT (6.54

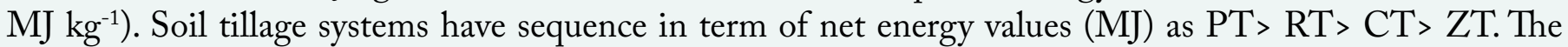
profitability of ZT, PT, RT and CT were $0.95,0.69,0.52$ and 0.32 . The economic analysis results described that intense application of agricultural machinery and operations were caused more energy consumption and reduction of energy use efficiency and may compromised on net energy and profitability of agroecosystems eventually. In rainfed agriculture system, all types of tillage as zero, reduced, and conservational systems could be applied instead of conventional tillage system in wheat farming according to studied energy parameters.

Received | April 10,2020; Accepted | September 4, 2020; Published | October 09, 2020

*Correspondence | Yong Sun, Department of Agriculture, Biological, Environment and Energy Engineering, College of Engineering, Northeast Agricultural University, Harbin 150030, China; Email: sunyong@neau.edu.cn

Citation | Noor, R.S., F. Hussain, I. Abbas, M. Umair, A. Saad, M.U. Farooq and Y. Sun. 2020. Assessing sustainability of rainfed wheat (Triticum aestivum) production under various soil tillage systems: An energy and economic analysis. Pakistan Journal of Agricultural Research, 33(4): 810-819. DOI | http://dx.doi.org/10.17582/journal.pjar/2020/33.4.810.819

Keywords | Soil tillage systems, Yield, Fuel consumptions, Energy use analysis, economics

\section{Introduction}

$\mathrm{I}$ $\mathrm{n}$ recent years, sustainable agricultural practices have been brought to the agenda in order to protect the natural ecosystem and especially the more sensitive agroecosystem both in the world and in our country, in order to protect soil and increase soil fertility. Sustainable agriculture; soil, water and air, considering environmental factors, human, plant and animal health is the idea of producing production 
(Chappell et al., 2011; Noor et al., 2020a).

Efficiency increases with the increase in energy input. However, the excessive increase in energy input may cause some economic damages. For energy efficiency, either efficiency should be increased, or inputs should be reduced. Increasing efficiency can be achieved within certain limits (Noor et al., 2020b). However, since energy efficiency can be reduced by the conscious application of inputs, it is important to calculate the energy balance of the systems used in production (Smith et al., 2015).

Usage of energy resources efficiency is the leading protocol for sustainable agricultural production systems which ensured; fossil resources are conserved, and it is possible to reduce air pollution. In order to increase energy efficiency, steps should be taken to improve the production efficiency or to preserve energy-input without compromising efficiency (Muhammadi et al., 2011). Energy saving is therefore having a prior importance for overall sustainable agricultural production (Kang et al., 2009).

Efficient and effective energy use for improved crop production is necessary to supply the optimum energy (Muhammadi and Omid, 2010). In the recent practices of agriculture production, crop seed, fertilizer and chemicals are the main crop inputs that consume energy in the shape of fuel, electricity (Hatirli et al., 2006). Tillage system is considered as the biggest energy and labor consumer in agricultural production i.e. the primary tillage requires $75 \%$ of the total energy consumed prior to plantation (Noor et al., 2019). Therefore, by choosing the suitable tillage system; environmental pollution control of systems and determination of energy protection (Tabatabaeefar et al., 2009).

Moitzi et al. (2006) stated that $30 \%$ of filed energy is consumed in tillage; Jacobs et al. (2010) found that reducing tillage reduces fuel consumption by $55 \%$ having no significant effect of yield; Taner et al. (2015), direct planting and reduced tillage systems with $84 \%$ and $54 \%$ reduction in the use of towing energy reported (Tabatabaeefar et al., 2009).

Marakoglu and Carman (2010) investigated the energy budget of spinner and spine planting methods in wheat agriculture, they stated that the energy ratio was 6.63 in spike planting and 5.29 in spine planting.
Jin et al. (2007) conducted the comparative study on the energy efficiency for wheat production under different soil tillage by comparing, they determined the energy ratio for traditional and direct planting as 3.65 and 4.87, respectively. Aslam et al. (2020a) stated that direct sowing with the highest output/input ratio is a more profitable production technique in their studies where 5 different tillage systems determine the energy balance in wheat production.

Similar results were obtained in another study that the output/input ratio in direct sowing practices in wheat production was determined as 2.81 (Marakoglu and Carman, 2010). Sharma et al. (2011) stated that for winter wheat, $315.32 \mathrm{MJ} \mathrm{Mg}^{-1}$ was spent in Conventional Tillage and $192.38 \mathrm{MJ} \mathrm{Mg}^{-1}$ expenditure was used for conservation tillage while $39.1 \%$ savings were achieved in direct sowing system and $85.1 \%$ savings were achieved with $47.14 \mathrm{MJ}$ Mg-1 (Tabatabaeefar et al., 2009).

Alluvione et al. (2011) compared energy efficiency in wheat production in different climatic regions and assessed the energy, economy and environmental benefits resulting from selected energy conservation measures. They predicted different energy conservation measures depending on climate and country. They stated that indirect and direct energy inputs are largely specific to geographic location and climate zones, and that the increase in efficiency in climate zones is parallel to the increase in total energy inputs. They stated that energy consumption and energy saving potential in each agricultural production system differ in specific geographical areas and climate regions (Aslam et al., 2020b).

Sustainable agricultural production system in wheat cultivation under dry farming conditions as the main product, energy management is an essential component (Noor et al., 2020c). Therefore, we studied the impact of four soil tillage methods on wheat yield, fuel usage and energy use efficiency under rainfed agriculture systems. This study performed complete energy and economic budget in order to recommend a sustainable and economical practice for wheat sowing in rainfed agriculture system.

\section{Materials and Methods}

\section{Study area}

These study trails were carried out during 2017-18 
and 2018-19 wheat seasons at Koont research station Chakwal, PMAS-Arid Agriculture University, Rawalpindi. The farm location on the world globe is between $33^{\circ} 1^{\prime}$ to $33^{\circ} 6^{\prime} \mathrm{N}$ and $73^{\circ} 30^{\prime}$ to $73^{\circ} 45^{\prime} \mathrm{E}$. Soil texture type was sandy clay loam (56\% sand, $22.8 \%$ silt, $21.2 \%$ clay) with a $\mathrm{pH}$ of 7.7 at experimental site. Average rainfall and temperature during the crop seasons were shown in Figure 1. The soil physiochemical properties of trail field were presented in Table 1. The climatic condition is semi-arid sub humid while the rainfall is in bi-seasonal with maturity in late summer and winter. Monsoon season generally have $60-70 \%$ of total rainfall ( $15^{\text {th }}$ June $-15^{\text {th }}$ September). However, winter rain occurs as gentle showers persist prolong, and thus, are more favorable in aspect of agricultural production (Shafiq et al., 2005). Average monthly rainfall and temperature data were also monitored.

Table 1: Some soil characteristics at the beginning of the study.

\begin{tabular}{lll} 
Soil characteristics & \multicolumn{2}{c}{ Soil depth } \\
& $\mathbf{0 - 1 5} \mathrm{cm}$ & $\mathbf{1 5 - 3 0} \mathrm{cm}$ \\
Soil moisture content (\%) & 14.73 & 14.73 \\
Soil bulk density $\left(\mathrm{g} \mathrm{cm}^{-3}\right)$ & 1.45 & 1.45 \\
Soil pH & 7.7 & 7.6 \\
Total salt (\%) & 0.01 & 0.02 \\
Lime (\%) & 9.81 & 9.67 \\
Soil organic matter $\left(\mathrm{g} 100 \mathrm{~g}^{-1}\right)$ & 5.9 & 5.8 \\
Total nitrogen $(\mu \mathrm{g} \mathrm{g}-1)$ & 4.9 & 4.2 \\
Available phosphorus $\left(\mathrm{P} 2 \mathrm{O} 5, \mu \mathrm{g} \mathrm{g}^{-1}\right)$ & 3.2 & 3.0 \\
Available potassium $\left(\mathrm{K} 2 \mathrm{O}, \mu \mathrm{g} \mathrm{g}^{-1}\right)$ & 142 & 139
\end{tabular}

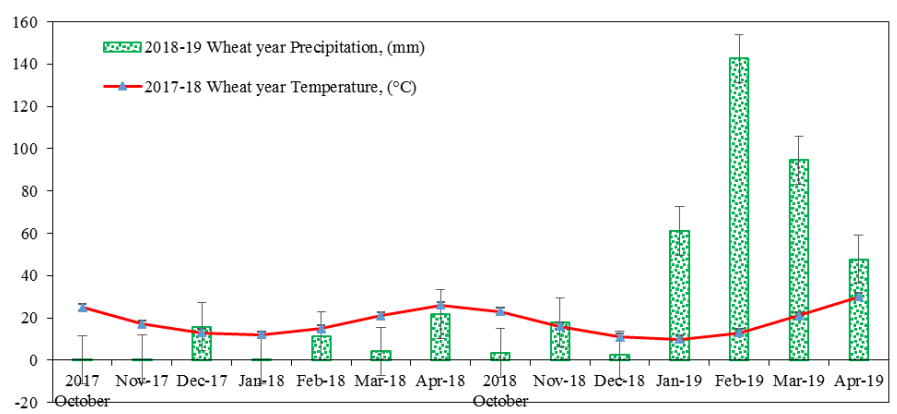

Figure 1: Temperature and precipitation data of the trial area.

\section{Soil tillage systems}

The experiment was conducted in 12 subplots of area 2,023 $\mathrm{m}^{2}(0.5$ acre $)$ each with 3 replications laid out as completely randomized design (CRD). Study consisted of conventional tillage (CT), conservational tillage (PT), reduced tillage (RT) and zero/no tillage $(Z T)$. Zero tillage included directly seeding with no soil disturbance. RT treatment was performed one (1) pass mouldboard plough and wheat seed drill. The PT system included once Chisel plow, disc harrow and seed drill. In CT systems was applied using once mouldboard ploughing at 30-35 cm depth, one pass Chisel plough, one pass disc harrow for soil pulverizing before drill sowing. Agricultural equipment used for plant protection, harvesting and transporting were same in all tillage systems. Fait 385 4WD tractor with $85 \mathrm{HP}$ power was used for all operations in the experiment. The list of Agricultural machinery used in this experiment were given in the Table 2.

Table 2: Some features of the machines used in the study.

\begin{tabular}{|c|c|c|c|c|}
\hline Machine & No. of units & $\begin{array}{l}\text { Width } \\
\text { (cm) }\end{array}$ & $\begin{array}{l}\text { Depth } \\
(\mathrm{cm})^{*}\end{array}$ & $\begin{array}{l}\text { Weight } \\
\text { (kg) }\end{array}$ \\
\hline Tractor, 685S, 4WD & - & - & - & 3011 \\
\hline M.B. plow & 3 furrows & 90 & 25 & 355 \\
\hline Chisel plow & 9 tines & 270 & $25-40$ & 350 \\
\hline Rotovator & 54 blades & 214 & 15 & 585 \\
\hline Disc harrow & 20 Disc & 290 & $100-150$ & 555 \\
\hline Zero-till drill & 11 rows & 250 & 6 & 250 \\
\hline Wheat drill & 11 rows & 250 & $5-8$ & 300 \\
\hline Reaper & 6 crop dividers & 147 & $10-30^{* * *}$ & 116 \\
\hline
\end{tabular}

The sowing process was carried out at $125 \mathrm{~kg} / \mathrm{ha}$ seed rate and $5 \mathrm{~cm}$ sowing depth. The sowing tractor speed was measured $5.1 \mathrm{~km} / \mathrm{h}$ by measuring time to cover 100 meters (Soomro et al., 2009). ASAE 1999 and ASAE 2011 standards were followed for feed rate of other agricultural machinery. Chakwal-50 wheat variety was used in this study. The suggested 120 , 30 and $33 \mathrm{kgha}^{-1}$ of $\mathrm{N}, \mathrm{P}$ and $\mathrm{K}$, respectively were fed to the field as Urea-fertilizer (46\% nitrogen), diammonium phosphate (18\% N and 20\% P) and potash $(50 \% \mathrm{~K})$ (Yadava et al., 2016).

\section{Wheat yield and fuel consumptions}

Yield was calculated as $\mathrm{kg} / \mathrm{ha}$ by harvesting all the plants in the middle two rows of each parcel. Fuel consumption values of tillage and sowing machinery were measured using the following equations (Mileusnić et al., 2010). The fuel consumptions of centrifugal manure spreader and combine harvester, lubrication oil consumption was taken as $5 \%$ of fuel consumed (Fluck, 1985).

$$
D i=F_{i} \times\left\{A_{m}+\left(B_{m} \times S\right)+\left(C_{m} \times S_{2}\right)\right\} \times W T
$$




$P T=\left(D_{i} \times S\right) /\left(3.6 E_{m} E_{t}\right) \ldots(2)$
$Q_{d}=P T\left\{2.64\left(P T / P T_{m}\right)+3.91-0.203 \sqrt{ } 738(P T /\right.$
$\left.P T_{m}\right)+173 \ldots(3)$
$C_{a}=\left(S \times W \times E_{f}\right) / 10 \ldots(4)$

Where;

$\mathrm{D}_{\mathrm{i}}=$ traction force $(\mathrm{N}), \mathrm{F}_{\mathrm{i}}=$ soil textural class (dimensionless), $\mathrm{A}_{\mathrm{m}} \mathrm{B}_{\mathrm{m}} \mathrm{C}_{\mathrm{m}}=$ specified parameter specified for agricultural machinery, $\mathrm{S}=$ operating speed $\mathrm{Kmh}^{-1}$, W= implement working width $(\mathrm{m}), \mathrm{T}=$ implement depth $(\mathrm{cm}), \mathrm{E}_{\mathrm{m}}=$ mechanical efficiency of tractor (0.96), $\mathrm{E}_{\mathrm{t}}=$ draft efficiency, $\mathrm{Q}_{\mathrm{t}}=$ diesel consumption $(1 / \mathrm{h}), \mathrm{PT}=$ total power required for work $(\mathrm{kW}), \mathrm{PT}_{\mathrm{m}}=$ maximum power at $\mathrm{PTO}(\mathrm{kW})$, $\mathrm{C}_{\mathrm{a}}=$ field capacity hah ${ }^{-1}$ and $\mathrm{E}_{\mathrm{f}}=$ field efficiency.

Quantity of diesel fuel consumed per unit field area $(1 / \mathrm{ha})$ was measured by multiplication of fuel consumption per unit time (Equation 3) and fied capacity (Equation 4). The numerical values of all parameters were mentioned in Table 3.

Table 3: The numerical values of the machine's parameters used in the calculation of fuel consumption.

$\begin{array}{lllllll} & \mathbf{A} & \mathbf{B} & \mathbf{C} & \mathbf{F}_{\mathbf{i}} & \mathbf{E}_{\mathbf{t}} & \mathbf{E f} \\ \text { M.B. plow } & 652.00 & 0.00 & 5.10 & 0.70 & 0.77 & 0.85 \\ \text { Chisel plow } & 91.00 & 5.40 & 0.00 & 0.85 & 0.77 & 0.85 \\ \text { Rotovator } & 600.00 & 0.00 & 0.00 & 1.00 & 0.77 & 0.85 \\ \text { Disc harrow } & 216.00 & 11.20 & 0.00 & 0.88 & 0.75 & 0.80 \\ \text { Wheat seed drill } & 300.00 & 0.00 & 0.00 & 1.00 & 0.75 & 0.70 \\ \text { Direct seeder } & 720.00 & 0.00 & 0.00 & 0.79 & 0.77 & 0.70\end{array}$

(ASAE, 1999; ASAE, 2011).

\section{Energy analysis}

Total production energy (MJ) (inputs and outputs energies) consumed in each treatment was calculated per unit area (hectare). Table 4 showed all energy equivalents for all crop factors used in the wheat production under various farming treatments. Energy indices were measured by applying energy inputs, energy output and grain yield given in the equation below (Khan et al., 2009; Pishgar et al., 2012; Yousefi et al., 2014b).

Energy ratio= Total energy (output) / Total energy (input) ...(5)

Specific energy $\left(M J k^{-1}\right)=$ Total energy (input) / wheat yield ...(6)

Energy efficiency $\left(\mathrm{kg} M J^{-1}\right)=$ Wheat yield $/$ Total energy (input) ...(7)
Net energy $\left(M J \mathrm{Ja}^{-1}\right)=$ Total energy (output) - Total energy (input) ...(8)

Energy profit = Net energy/Total energy (input) ... (9)

\section{Economic analysis}

The economic analysis for different farming treatments included total costs, gross return, net return, profitability and net energy value were calculated by equations $10-12$.

Net return $\left(\$ h a^{-1}\right)=$ gross return - Total input cost ...(10) Profit $=$ Net return $/$ Total input cost $\ldots$... (11)

Net specific energy $\left(\$ M J^{-1}\right)=$ Total costs $/$ Net energy ...(12)

\section{Statistical analysis}

The obtained research data was analyzed under ANOVA and multiple comparison test using SPSS22 statistical software.

\section{Results and Discussion}

\section{Wheat yield and fuel consumptions}

Wheat yield harvested from different soil tillage treatments was presented in Table 5 . The wheat yield $(\mathrm{P}<0.01)$ was significantly affected by various soil tillage practices. Highest wheat yield was found in conventional tillage $\left(2,300 \mathrm{kgha}^{-1}\right)$ and the minimum wheat yield was observed in direct sowing system $\left(1,930 \mathrm{kgha}^{-1}\right)$. The treatments RT-PT, CT-RT and $\mathrm{PT}-\mathrm{ZT}$ showed no significant difference as given in Table 5 (Soomro et al., 2009).

Table 5 showed the fuel consumption and working time values in all the processes applied until the harvest in the treatments where soil tillage systems were applied. The sequence for fuel consumption in different tillage systems were found as $\mathrm{CT}>\mathrm{RT}>\mathrm{PT}>$ NT during both wheat seasons. Among the machines used, the M.B. plow was the implement with the highest fuel consumption. Compared to conventional tillage, average fuel consumption in RT, PT and NT systems were $46.95 \%, 47.04 \%$ and $77.88 \%$ during both wheat seasons, respectively (Table 6).

\section{Energy analysis}

Energy used for wheat production under different treatments was presented in Table 6. In this study, it was determined that the highest input share under all treatments was in fertilizer + manure energy and followed by seed, fuel + lubricating oil and machinery manufacturing energy. Soil cultivation systems were 
Table 4: List of energy equivalents for input and outputs in wheat production.

\begin{tabular}{|c|c|c|}
\hline Crop production parameters (units) & Enerfy equivalents (MJ unit ${ }^{-1}$ ) & Source \\
\hline Human labor $(\mathrm{h})$ & 1.96 & Muhammadi and Omid, 2010 \\
\hline Agricultural machinery (h) & 62.7 & Samavatean et al., 2010 \\
\hline Tractor $(\mathrm{h})$ & 158.3 & Samavatean et al., 2010 \\
\hline Diesel fuel (I) & 51.33 & Samavatean et al., 2010 \\
\hline \multicolumn{3}{|l|}{ Chemical fertilizer $(\mathrm{kg})$} \\
\hline Nitrogenous & 66.14 & Erdal et al., 2007 \\
\hline Phosphorus $\left(\mathrm{P}_{2} \mathrm{O}_{5}\right)$ & 12.44 & Erdal et al., 2007 \\
\hline Potassium $\left(\mathrm{K}_{2} \mathrm{O}\right)$ & 11.15 & Erdal et al., 2007 \\
\hline Farmyard manure $(\mathrm{kg})$ & 0.3 & Esengun et al., 2007 \\
\hline Lubrication oil (I) & 42.5 & Samavatean et al., 2010 \\
\hline \multicolumn{3}{|l|}{ Pesticides (kg) } \\
\hline Herbicides & 101.2 & Ghiyasi et al., 2008 \\
\hline Insecticides & 199 & Gundogmus, 2006 \\
\hline Electricity (kWh) & 3.6 & Rafiee et al., 2010 \\
\hline Irrigation water $\left(\mathrm{m}^{3}\right)$ & 1.02 & Samavatean et al., 2010 \\
\hline Seed + fungicides $(\mathrm{kg})$ & 17.6 & Ghiyasi et al., 2008 \\
\hline Wheat grain $(\mathrm{kg})$ & 14.7 & Yousefi et al., 2016 \\
\hline Straw $(\mathrm{kg})$ & 12.5 & Yousefi et al., 2016 \\
\hline
\end{tabular}

Table 5: Wheat yield and fuel consumption values in soil tillage systems.

\begin{tabular}{|c|c|c|c|}
\hline Soil tillage Systems (Treatments) & Yield $\left(\mathrm{kg} \mathrm{ha}^{-1}\right)^{*}$ & Fuel consumption $\left(1 \mathrm{ha}^{-1}\right)$ & Field Capacity $\left(\mathrm{h} \mathrm{ha}^{-1}\right)$ \\
\hline Zero tillage system $(\mathrm{ZT})$ & $1930 \mathrm{c}$ & 8.97 & 3.50 \\
\hline Conservational tillage system (PT) & $2135 \mathrm{bc}$ & 21.50 & 5.00 \\
\hline Reduced tillage system (RT) & $2222 \mathrm{ab}$ & 22.73 & 4.90 \\
\hline Conventional tillage system (CT) & $2300 \mathrm{a}$ & 40.56 & 5.76 \\
\hline
\end{tabular}

* There is no statistical difference between the applications indicated by the same letter in the column.

Table 6: Total energy used under different soil treatments of wheat production ( $\left.M J \mathrm{ha}^{-1}\right)$.

\section{Inputs and outputs}

$\begin{array}{lllll} & \text { ZT } & \text { PT } & \text { RT } & \text { CT } \\ \text { Human labor force } & 7.3 & 10.44 & 10.21 & 12.06 \\ \text { Machinery manufacturing } & 664.87 & 591.22 & 612.73 & 662.79 \\ \text { Fuel + Oil } & 483.45 & 1158.78 & 1225.06 & 2186.04 \\ \text { Fertilizer + manure } & 10477.95 & 10477.95 & 10477.95 & 10477.95 \\ \text { Seed } & 2200 & 2200 & 2200 & 2200 \\ \text { Total inputs } & 13833.5716 & 14438.38 & 14525.96 & 15538.842 \\ \text { Wheat } & 28,371.00 & 31,384.50 & 32,663.40 & 33,810.00 \\ \text { Straw } & 47375 & 55700 & 54300 & 46062.5 \\ \text { Total output } & 75,746.00 & 87,084.50 & 86,963.40 & 79,872.50\end{array}$

\section{Soil tillage systems}

listed as $\mathrm{CT}>\mathrm{RT}>\mathrm{PT}>\mathrm{ZT}$ in terms of total energy inputs. The input that makes a difference in the energy inputs of the tillage systems was fuel+lubricating oil, machinery manufacturing and manpower energy input. Fuel + lubricating oil energy input $\%$ of total energy input in the ZT system 3.49, while constituting $8.03 \%, 8.43 \%$ and $14.07 \%$ of the PT, RT and CT systems, respectively (Table 6). Similarly, the highest proportion as total energy input in wheat production were both fertilizer input and seed oil input and fuel oil energy input, respectively (Marakoglu and Carman, 2010). The percentage share of different energy input sources in wheat production under various tillage systems were shown in Figure 2. 
Table 7: Energy analysis of tillage systems under wheat production.

Energy parameters

$\begin{array}{lllll} & \text { ZT } & \text { PT } & \text { RT } & \text { CT } \\ \text { Energy Ratio } & 5.48 \mathrm{~b} & 6.03 \mathrm{a} & 5.99 \mathrm{a} & 5.14 \mathrm{~b} \\ \text { Specific Energy }\left(\mathrm{MJ} \mathrm{kg}^{-1)}\right. & 7.17 \mathrm{a} & 6.76 \mathrm{a} & 6.54 \mathrm{c} & 6.76 \mathrm{~b} \\ \text { Energy Efficiency }\left(\mathrm{kg} \mathrm{MJ}^{-1}\right) & 0.14 \mathrm{a} & 0.15 \mathrm{a} & 0.15 \mathrm{a} & 0.15 \mathrm{a} \\ \text { Net Energy }\left(\mathrm{MJ} \mathrm{ha}^{-1}\right) & 61912.43 \mathrm{~b} & 72646.12 \mathrm{a} & 72437.44 \mathrm{a} & 64333.66 \mathrm{~b} \\ \text { Energy Profitability } & 4.48 \mathrm{~b} & 5.03 \mathrm{a} & 4.99 \mathrm{a} & 4.14 \mathrm{c}\end{array}$

Table 8: Economic analysis of wheat production under ZT, RT and CT systems.

$\begin{array}{lllll}\text { Cost and revenues } & \text { ZT } & \text { RT } & \text { PT } & \text { CT } \\ \text { Wheat yield }(\mathrm{kg} / \mathrm{ha}) & 1930 & 2135.00 & 2222 & 2300.00 \\ \text { Straw yield }(\mathrm{kg} / \mathrm{ha}) & 3790.00 & 4456.00 & 4344.00 & 3685.00 \\ \text { Sale price }(\$ / \mathbf{1 0 0 0} \mathrm{kg}) & & & & \\ \text { Wheat grain } & 240 & 240 & 240 & 240 \\ \text { Wheat straw } & 50 & 50 & 50 & 50 \\ \text { Net energy }(\mathrm{MJ} / \mathrm{ha}) & 61912.43 & 72646.12 & 72437.44 & 64333.66 \\ \text { Input costs }(\$ / \mathbf{1 0 0 0} \mathrm{kg}) & & & & \\ \text { Agricultural machinery and diesel } & 60.00 & 70.00 & 80.00 & 90.00 \\ \text { Fertilizer }(\text { manure + chemical) } & 45.00 & 45.00 & 45.00 & 45.00 \\ \text { Human labor } & 22.00 & 35.00 & 46.00 & 66.00 \\ \text { Pesticides } & 12.00 & 12.00 & 12.00 & 12.00 \\ \text { Water and electricity } & 0.00 & 0.00 & 0.00 & 0.00 \\ \text { Seed + fungicides } & 13.00 & 13.00 & 13.00 & 13.00 \\ \text { Transportation } & 2.00 & 2.00 & 2.00 & 2.00 \\ \text { Total cost of production } & 154.00 & 177.00 & 198.00 & 228.00 \\ \text { Revenues }(\$ / 1000 \mathrm{~kg}) & & & & \\ \text { Grain yield } & 250.00 & 250.00 & 250.00 & 250.00 \\ \text { Straw yield } & 50.00 & 50.00 & 50.00 & 50.00 \\ \text { Gross return } & 300.00 & 300.00 & 300.00 & 300.00 \\ \text { Net return } & 146.00 & 123.00 & 102.00 & 72.00 \\ \text { Profitability } & 0.95 & 0.69 & 0.52 & 0.32 \\ \text { Net energy value }(\$ / M J) & 0.002 & 0.002 & 0.003 & 0.004\end{array}$

Ghorbani et al. (2011) calculated the total energy in wheat production under irrigated and rainfed conditions were 45,367 MJha-1 and 9,354 MJha1, respectively. Yuan et al. (2018) measured the total input energies in wheat production were $18,392.10$ MJ ha ${ }^{-1}$ at flat sowing and 18,494.01 $\mathrm{MJ} \mathrm{ha}^{-1}$ at ridge. In our study, when the energy output values were examined, the optimal output energy was gained from PT and RT systems while, the lowest energy output was obtained in the ZT system as in the efficiency values (Table 6). In order to express how efficiently the input sources were used in wheat production and how effectively it was transformed to output, soil tillage systems should be compared according to the energy parameters given in Table 8. The ANOVA results depicted a significant impact on the energy parameters of soil tillage systems statistically $\mathrm{P}<0.01$ level. Multiple comparison test results and average values to see the difference between tillage systems (Table 7). The highest energy ratio was measured in PT (6.03) and RT (5.99) treatments while, the lowest energy ratio was in the $\mathrm{CT}$ treatment. Although the yield was the highest in the Conventional Tillage system, the high energy input has caused the energy rate to be lower than other systems. Although the efficiency was low in the NT application, the low energy input has also increased the rate. Ghorbani et al. (2011) determined the energy ratios was 3.38 
and 1.44 in rainfed and irrigated wheat production, respectively.
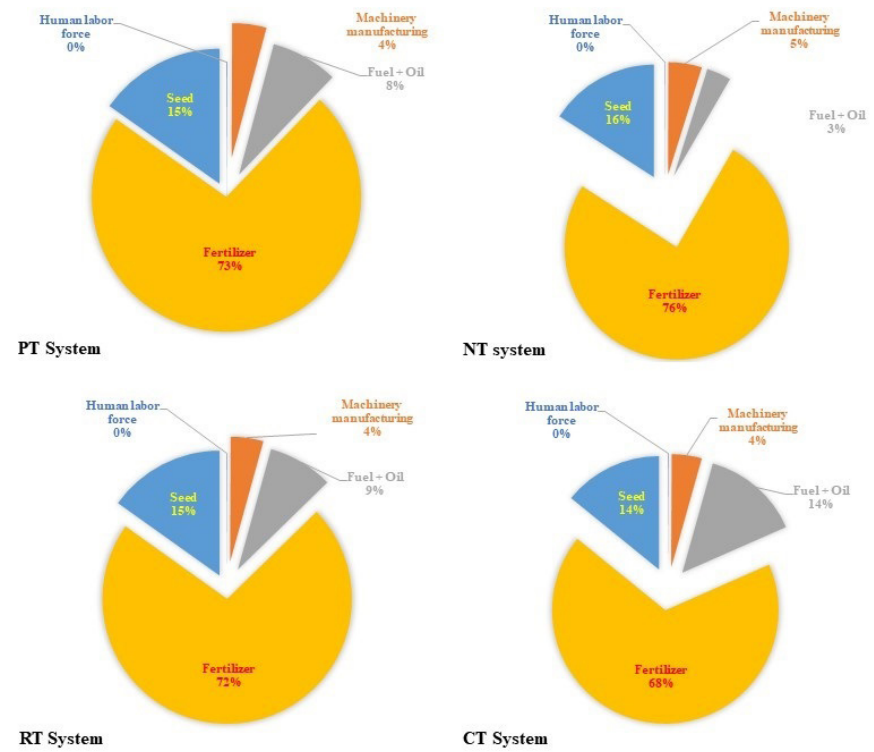

RT System

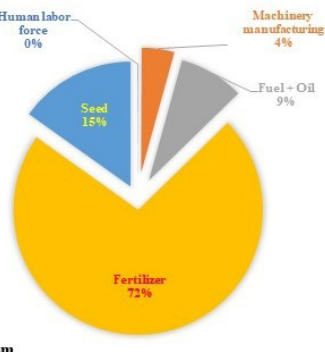

CT System

Figure 2: The (\%) share of different energy input sources in ZT, PT, $R T$ and CT systems (Human labor force energy equivalent in all soil tillage systems were measured below $1 \%$ of total input energy for wheat production).

Soil cultivation treatments were found in the sequence as $\mathrm{PT}>\mathrm{RT}>\mathrm{ZT}>\mathrm{CT}$ in terms of energy ratio. To produce $1 \mathrm{~kg}$ wheat yield, the energy requirement was 6.54 MJ and 6.76 MJ in RT and CT treatments, whereas in PT and ZT systems 6.76 MJ and 7.17 MJ energy were required (Table 7). In the study of Marakoglu and Carman (2010) stated that the energy value $2.08 \mathrm{MJ}$ in the flat sowing method, while it was 2.61 MJ in the back sowing method, and (Sial, 2005) $6.20 \mathrm{MJ}$.

According to the results of the study, $0.15 \mathrm{~kg}$ wheat was produced with $1 \mathrm{MJ}$ energy in CT, RT and PT systems, and this value was determined as $0.14 \mathrm{~kg}$ in ZT systems. In addition, energy profitability was determined to be the lowest in the CT system (Table 7).

When the net energy values of the systems are examined; It was observed that the highest value was obtained with 64,333.66 $\mathrm{MJha}^{-1}$ in CT treatment while the lowest was obtained with $61,912.43 \mathrm{MJ} \mathrm{ha}^{-1}$ in the ZT system. According to multiple comparison test results; There were no statistically significant difference between PT and RT systems in energy parameters other than net energy gain. In terms of net energy gain, PT and RT systems were in the same group statistically. Considering the net energy gain, Conservational Tillage should be preferred in wheat agriculture in the region. However, considering the other energy parameters, the statistical results in the study area, in terms of energy use in rainfed agricultural conditions instead of conventional tillage, protective tillage or reduced tillage systems should be used. Chappell et al. (2011) in their study by considering the energy ratio of the recommendations and wheat and chickpea production has the highest energy rate recommended direct herbicide + planting application. Studies on the determination of energy efficiency in wheat agriculture (Tabatabaeefar et al., 2009; Ghorbani et al., 2011; Sial, 2005; Chappell et al., 2011; Marakoglu and Carman, 2010) energy parameters change according to factors such as climate, soil properties and applied methods. These results demonstrate the importance of identifying suitable management for crop production in different geographical areas and climatic zones for sustainable agricultural production.

\section{Economic analysis}

The experimental results of economic analysis of wheat production were presented in Table 8. The higher costs in wheat production were paid for Agricultural machinery and diesel fuel consumed, maximum in PT $(40.40 \%$ of total cost), while the cost under wheat cultivation for fertilizer + manure (ranged $19.73-29.22 \%$ of total cost of production). Wheat production profitability with ZT, RT, PT and CT systems were $0.95,0.69,0.52$ and 0.32 respectively. This indicated that more beneficial per unit cost in wheat production ZT system. Previous studies were reported profitability calculated as 1.10 in soyabean, 1,98 in mustard, 2.03 in wheat and 2.30 in chickpea, while 2.13 and 2.14 were obtained in apricot production under organic and inorganic treatments (Gundogmus, 2006). Similarly, wheat production with ZT, RT and PT systems were more profitable ratio to CT system (Muhammadi and Omid, 2010; Esengun et al., 2007; Ghiyasi et al., 2008), in ZT system was obtained 1.24 , which was comparatively more beneficial than that of CT system. High cost of the tillage was the main reason in these tillage systems rather to NT system (Rafiee et al., 2010; Samavatean et al., 2010).

The cost spent for unit energy for different farming treatments of wheat production were calculated $0.002 \$ / \mathrm{MJ}$ for ZT and RT systems while maximum was $0.004 \$ / \mathrm{MJ}$ which revealed that optimal cost of $1 \mathrm{MJ}$ of net energy in CT treatment compared 
to other treatments. Increasing crop yield and diminishing production cost will lead to enhance the wheat production. So, the production ration in all treatments is higher as compared to CT treatment. In this way we can maintain the crop productivity at a desired stage and remain sustainable by optimizing the energy consumption level.

\section{Conclusions and Recommendations}

This study evaluated four tillage treatments in wheat production under rainfed conditions to develop a sustainable wheat production practice. For this purpose; wheat yield, fuel consumption, energy and economic analysis were determined for each tillage system. The energy budget revealed Conventional tillage as expensive treatment while lowest input and output values were obtained from direct sowing system. Fertilizer, seed and fuel + oil had the highest share in total input energy. Energy ratio, specific energy, energy ratio and energy profitability according to the values of reduced soil tillage has been the best results. Besides; Since sowing, conservational/ protective tillage and reduced tillage treatments showed no significant difference. It is concluded that these methods should be used in terms of efficient energy use instead of traditional method in wheat agriculture in the region.

\section{Acknowledgement}

The authors acknowledge the PMAS-Arid Agriculture University Rawalpindi, Pakistan for providing the research facilities. The authors are thankful and acknowledged the Northeast Agricultural University, Harbin, China for their technical scientific support.

\section{Novelty Statement}

In this research study, we studied the impact of four soil tillage methods on wheat yield, fuel usage and energy use efficiency under rainfed agriculture systems. This study performed complete energy and economic budget in order to recommend a sustainable and economical practice for wheat sowing in rainfed agriculture system.

\section{Author's Contributions}

Rana Shahzad Noor conceived the conceptualization of research study, design and development of December 2020 | Volume 33 | Issue 4 | Page 817 the experiment, data collection, formal analysis, investigation, methodology, visualization, writing an original draft, reviewed, supervised and write-up editing. Fiaz Hussain contributed in data collection, formal analysis, investigation, methodology, visualization and writing an original draft. Irfan Abbas, Muhammad Umar Farooq and Abu Saad contributed in data collection and data formal analysis. Muhammad Umair contributed to perform formal analysis of this manuscript. Yong Sun supervised the entire research work. Prof. Dr. Yong Sun contributed as internal reviewer for the manuscript.

\section{Conflict of interest}

The authors have declared no conflict of Interest.

\section{Source of funding}

This research received no external funding.

\section{References}

Alluvione, F., B. Moretti, D. Sacco and C. Grignani. 2011. EUE (energy use efficiency) of cropping systems for a sustainable agriculture. Energy, 36(7): 4468-4481. https:// doi.org/10.1016/j.energy.2011.03.075

Aslam, W., R.S. Noor, S. Ullah and H. Chen. 2020a. Comparative economic analysis of crop yield under organic and conventional farming systems in Punjab, Pakistan. Asian J. Agric. Biol., 8(2): 113-118. https://doi.org/10.35495/ ajab.2020.02.093

Aslam, W., R.S. Noor, S. Ullah and H. Chen. 2020b. Factors influencing organic production and consumption approaches of consumers: a case study of Punjab province. Asian J. Agric. Biol., 8(3): 274-280. https://doi.org/10.35495/ ajab.2020.02.105

Chappell, M.J. and L.A. LaValle. 2011. Food security and biodiversity: can we have both? An agroecological analysis. Agric. Human Values, 28(1): 3-26. https://doi.org/10.1007/ s10460-009-9251-4

Erdal, G., K. Esengun, H. Erdal and O. Gunduz. 2007. Energy use and economic analysis of sugar beet production in Tokat province of Turkey. Energy, 32(1): 35-41. https://doi. org/10.1016/j.energy.2006.01.007

Esengun, K., O. Gunduz and G. Erdal. 2007. Input-output energy analysis in dry apricot production of Turkey. Energy Convers. Manage., 
48(2): 592-598. https://doi.org/10.1016/j. enconman.2006.06.006

Fluck, R.C., 1985. Energy sequestered in repairs and maintenance of agricultural machinery. Trans. ASAE, 28(3): 738-744. https://doi.org/10.13031/2013.32330

Ghiyasi, M., M. Myandoab, M. Tajbakhsh, A. Hasanzade-Gorttape, M.V. Meshkat and H. Salehzade. 2008. The evaluation of energy balance of wheat under low input farming in West Azerbaijan. Res. J. Biol. Sci., 12(3): 14081410.

Ghorbani, R., F. Mondani, S. Amirmoradi,H. Feizi, S. Khorramdel,M.Teimouri and H.Aghel.2011. A case study of energy use and economic analysis of irrigated and dryland wheat production systems. Appl. Energy, 88(1): 283-288. https:// doi.org/10.1016/j.apenergy.2010.04.028

Gundogmus, E., 2006. Energy use on organic farming: A comparative analysis on organic versus conventional apricot production on small holdings in Turkey. Energy Convers. Manage., 47(18-19): 3351-3359. https://doi. org/10.1016/j.enconman.2006.01.001

Hatirli, S.A., B. Ozkan and C. Fert. 2006. Energy inputs and crop yield relationship in greenhouse tomato production. Renewable Energy, 31(4): 427-438.

https://doi.org/10.1016/j. renene.2005.04.007

Jacobs, A., M. Helfrich, S. Hanisch, U. Quendt, R. Rauber and B. Ludwig. 2010. Effect of conventional and minimum tillage on physical and biochemical stabilization of soil organic matter. Biol. Fertil. Soils, 46(7): 671-680. https://doi.org/10.1007/s00374-010-0472-x

Jin, H., L. Hongwen, W. Xiaoyan, A.D. McHugh, L. Wenying, G. Huanwen and N.J. Kuhn. 2007. The adoption of annual subsoiling as conservation tillage in dryland maize and wheat cultivation in northern China. Soil Till. Res., 94(2): 493-502.

Kang, Y., S. Khan and X. Ma. 2009. Climate change impacts on crop yield, crop water productivity and food security $-\mathrm{A}$ review. Prog. Natl. Sci., 19(12): 1665-1674. https://doi. org $/ 10.1016 /$ j.pnsc.2009.08.001

Khan, S., M.A. Khan, M.A. Hanjra and J. Mu. 2009. Pathways to reduce the environmental footprints of water and energy input in food production. Food Policy. 34(2): 141-149. https://doi.org/10.1016/j.foodpol.2008.09.001
Marakoglu, T. and K. Carman. 2010. Energy balance of direct seeding applications used in wheat production in middle Anatolia. Afr. J. Agric. Res., 5(10): 988-992.

Mileusnić, Z.I., D.V. Petrović and M.S. Đević. 2010. Comparison of tillage systems according to fuel consumption. Energy, 35(1): 221-228. https://doi.org/10.1016/j.energy.2009.09.012

Mohammadi, A. and M. Omid. 2010. Economical analysis and relation between input energys and yield of greenhouse cucumber production in Iran. Appl. Energy, 87: 191-196. https://doi. org/10.1016/j.apenergy.2009.07.021

Mohammadi, A., S. Rafiee, S.S. Mohtasebi, S.H.M. Avval and H. Rafiee. 2011. Energy efficiency improvement and input cost saving in kiwifruit production using data envelopment analysis approach. Renewable Energy, 36(9):2573-2579. https://doi.org/10.1016/j.renene.2010.10.036

Moitzi, G., H. Weingartmann and J. Boxberger. 2006. Effects of tillage systems and wheel slip on fuel consumption. The union of scientistsrousse. Energy Effic. Agric. Eng., 7(9): 237242.

Noor, R.S., F. Hussain and M. Umair. 2020c. Evaluating selected soil physical properties under different soil tillage systems in arid southeast Rawalpindi, Pakistan. J. Clean WAS, 4(2): 41-45.

Noor, R.S., F. Hussain, M.U. Farooq and M. Umair. 2020b. Cost and profitability analysis of cherry production: The case study of district Quetta, Pakistan. Big Data Agric. (BDA), 2(2): 65-71.

Noor, R.S., Z. Wang, M. Umair, M. Ameen, M. Imran and Y. Sun. 2019. Performance evaluation of a water seed drill. Sustainability, 11: 137. https://doi.org/10.3390/su11010137

Noor, R.S., Z. Wang, M. Umair, M. Ameen, M.A. Misaal, Y. Sun. 2020a. Long-term application effects of organic and chemical fertilizers on soil health and productivity of taramira (Eruca Sativa L.) under rainfed conditions. J. Anim. Plant Sci., 30(4): 970-987. https://doi. org/10.36899/JAPS.2020.4.0113

Pishgar, K.S.H., M. Ghahderijani and P.Sefeedpari. 2012. Energy consumption and $\mathrm{CO}_{2}$ emissions analysis of potato production based on different farm size levels in Iran. J. Cleaner Prod., 33: 183-191. https://doi.org/10.1016/j. jclepro.2012.04.008

Rafiee, S., A.S.H. Mousavi and A. Mohammadi. 
2010. Modeling and sensitivity analysis of energy inputs for apple production in Iran. Energy, 35(8): 3301-3306. https://doi. org $/ 10.1016 /$ j.energy.2010.04.015

Samavatean, N., S. Rafiee, H. Mobil and A. Mohammadi. 2010. An analysis of energy use and relation between energy inputs and yield, costs and income of garlic production in Iran. Renewable Energy, 36(6): 1808-1813. https:// doi.org/10.1016/j.renene.2010.11.020

Shafiq, M., A. Rashid and A.G. Mangrio. 2005. Agricultural potential soil resources of the Pothwar plateau. Soil Environ., 24: 109-119.

Sharma, P., V.Abrol and R.K. Sharma. 2011.Impact of tillage and mulch management on economics, energy requirement and crop performance in maize wheat rotation in rainfed subhumid inceptisols, India. Eur. J. Agron., 34(1): 46-51. https://doi.org/10.1016/j.eja.2010.10.003

Sial, J.K., 2005. Tillage practices for wheat fields. Editorial Advisory Board E, 12(1): 106112.

Smith, L.G., A.G. Williams and B.D. Pearce. 2015. The energy efficiency of organic agriculture: A review. Renewable Agric. Food Syst., 30(3): 280-301. https://doi.org/10.1017/ S1742170513000471

Soomro, U.A., M.U. Rahman, E.A. Odhano, S. Gul and A.Q. Tareen. 2009. Effects of sowing method and seed rate on growth and yield of wheat (Triticum aestivum). World J. Agric. Sci., 5(2): 159-162.

Tabatabaeefar, A., H. Emamzadeh, M.G.
Varnamkhasti, R. Rahimizadeh and M. Karimi. 2009. Comparison of energy of tillage systems in wheat production. Energy, 34(1): 41-45. https://doi.org/10.1016/j.energy.2008.09.023

Taner, A., R.Z. Arisoy, Y. Kaya, I. Gültekin and F. Partigöç. 2015. The effects of various tillage systems on grain yield, quality parameters and energy indices in winter wheat production under the rainfed conditions. Fresenius Environ. Bull., 24: 1463-1473.

Yadav, S.S., M.L. Jakhar and L.R. Yadav. 2016. Response of taramira (Eruca sativa) to varying levels of FYM and vermicompost under rainfed conditions. J. Oilseed Brassica, 1(1): 49-52.

Yousefi, M., D.A. Mahdavi and M. Khoramivafa. 2014b. Energy consumption, greenhouse gas emissions and assessment of sustainability index in corn agroecosystems of Iran. Sci. Total Environ., 493: 330-335. https://doi. org/10.1016/j.scitotenv.2014.06.004

Yousefi, M., M.A. Damghani and M. Khoramivafa. 2016. Comparison greenhouse gas (GHG) emissions and global warming potential (GWP) effect of energy use in different wheat agroecosystems in Iran. Environ. Sci. Pollut. Res., 23(8): 7390-7397. https://doi. org/10.1007/s11356-015-5964-7

Yuan, S., S. Peng, D. Wang and J. Man. 2018. Evaluation of the energy budget and energy use efficiency in wheat production under various crop management practices in China. Energy, 160: 184-191. https://doi.org/10.1016/j. energy.2018.07.006 